\title{
Meningkatkan Hasil Belajar Matematika melalui Penerapan Pembelajaran Kooperatif Tipe Think Pair Share pada Siswa Kelas VII B SMP Negeri 10 Ujung Loe Kabupaten Bulukumba
}

\author{
Muhammad Awal Nur \\ Sistem Komputer, STMIK Bina Adinata, Bulukumba, Sulawesi Selatan \\ E-mail:awalnur10@gmail.com
}

\begin{abstract}
This research is a classroom action research that aims to know the improvement of mathematics learning outcomes through the application of Think-Pair-Share Cooperative Learning (TPS). The subjects of this study were students of Class VII B SMP Negeri 10 Ujung Loe Kab. Bulukumba in the odd semester of the academic year 2016/2017, with a total of 30 students, consisting of 15 men and 15 women. This classroom action procedure takes 2 cycles. Cycle I held 4 meetings and Cycle II held 4 meetings. Data collection is done by using learning result test and observation. The collected data were analyzed by using qualitative analysis and quantitative analysis. The result of this research showed that quantitative improvement of mathematics learning outcomes after the implementation of Think-PairShare (TPS) cooperative learning, in cycle I showed that the average of student's learning result was 39,50 from ideal score that might be reached 100, Standard deviation of 24.58 and is in the low category. There are 7 complete students (23,33\%) and 23 students (76,67\%), and in cycle II shows the average of student's learning result is 69,50 from ideal score that might be reached 100, standard Deviation of 24.99 and is in the high category. There are 21 complete students (70\%) and 9 (30\%) unfinished students. While qualitatively during the learning process takes place changes in student attitudes. This is marked by the increased activity and activity of students during the implementation of the teaching took place viewed from the observation sheet conducted during the study. From the analysis can be concluded that with the implementation of cooperative learning type Think-Pair-Share (TPS) there is an increase in the results of learning mathematics students of class VII B SMP Negeri 10 Ujung Loe Bulukumba
\end{abstract}

Keywords: Improve Learning Outcome, Think-Pair-Share (TPS).

\begin{abstract}
Abstrak
Penelitian ini adalah penelitian tindakan kelas (Classroom Action Research) yang bertujuan untuk mengetahui peningkatan hasil belajar matematika melalui penerapan pembelajaran Kooperatif Tipe Think-Pair-Share (TPS). Subjek penelitian ini adalah siswa Kelas VII B SMP Negeri 10 Ujung Loe Kab. Bulukumba pada semester ganjil tahun pelajaran 2016/2017, dengan jumlah siswa 30 orang, yang terdiri dari 15 orang laki-laki dan 15 orang perempuan. Prosedur tindakan kelas ini ditempuh dalam 2 siklus. Siklus I dilaksanakan 4 kali pertemuan dan Siklus II dilaksanakan 4 kali pertemuan. Pengumpulan data dilakukan dengan menggunakan tes hasil belajar dan observasi. Data yang terkumpul dianalisis dengan menggunakan analisis kualitatif dan analisis kuantitatif. Hasil penelitian menunjukkan secara kuantitatif terjadi peningkatan hasil belajar matematika siswa setelah diterapkannya pembelajaran kooperatif tipe Think-Pair-Share (TPS), yaitu pada siklus I menunjukkan bahwa rata-rata hasil belajar siswa sebesar 39,50 dari skor ideal yang mungkin dicapai yaitu 100, standar deviasi 24,58 dan berada pada kategori rendah. Siswa yang tuntas sebanyak 7 orang (23,33\%) dan siswa yang tidak tuntas sebanyak 23
\end{abstract}


orang $(76,67 \%)$ dan pada siklus II menunjukkan rata -rata hasil belajar siswa sebesar 69,50 dari skor ideal yang mungkin dicapai 100, standar deviasi 24,99 dan berada pada kategori tinggi. Siswa yang tuntas sebanyak 21 orang (70\%) dan siswa yang tidak tuntas sebanyak 9 orang (30\%). Sedangkan secara kualitatif selama proses belajar mengajar berlangsung terjadi perubahan sikap siswa. Hal ini ditandai dengan meningkatnya keaktifan dan aktifitas siswa selama pelaksanaan pengajaran berlangsung dilihat dari lembar observasi yang dilakukan selama penelitian. Dari analisis dapat disimpulkan bahwa dengan adanya penerapan pembelajaran kooperatif tipe Think-Pair-Share (TPS) ada peningkatan hasil belajar matematika siswa kelas VII B SMP Negeri 10 Ujung Loe Kabupaten Bulukumba

Kata Kunci: Meningkatkan Hasil Belajar, Kooperatif Tipe Think-Pair-Share (TPS)

\section{Pendahuluan}

Pada dasarnya semua guru menginginkan kompetensi terbentuknya sikap kerjasama antar siswa dalam menyelesaikan suatu masalah. Salah satu wujud kompetensi tersebut adalah keterampilan berfikir dan kerjasama siswa dalam proses pembelajaran sangat berpengaruh terhadap pencapaian tujuan pembelajaran. Melalui keaktifan siswa dan kerjasama diharapkan hasil belajar siswa akan mengalami peningkatan. Salah satu cara untuk mengembangkan kompetensi siswa dalam kerjasama adalah melalui pembelajaran kooperatif yang berfokus pada penggunaan sekelompok kecil siswa untuk bekerjasama dalam rangka memaksimalkan kondisi belajar untuk mencapai tujuan pembelajaran. Berdasarkan survey awal, diperoleh informasi dari guru bidang studi matematika kelas VII B SMP Negeri 10 Ujung Loe Kab. Bulukumba yang bernama Nurmiati, S.Pd, mengatakan bahwa tingkat penguasaan siswa kelas VII B terhadap mata pelajaran matematika masih jauh tertinggal jika dibandingkan mata pelajaran lainnya dan tergolong rendah. Hal ini dilihat dari skor rata-rata hasil belajar siswa kelas VII B pada saat diberikan ulangan harian hanya berkisar 45 dari skor ideal 100, belum memenuhi secara klasikal KKM yang ditetapkan di SMP Negeri 10 Ujung Loe Kab. Bulukumba sebesar 65 . Sehingga, masih banyak siswa harus mengikuti program remedial untuk dapat mencapai batas tuntas yang telah ditetapkan oleh sekolah. Hal ini disebabkan, karena guru masih menggunakan model pembelajaran lebih banyak berpusat pada guru. Sehingga, siswa masih terlihat kurang aktif dan cenderung bersikap individual. Nampak pula adanya siswa yang bersifat 


\section{Meningkatkan Hasil Belajar Matematika...}

tertutup dan malu bertanya kepada guru mengenai materi pelajaran yang belum dimengerti. Berdasarkan permasalahan yang dikemukakan diatas, maka upaya yang dilakukan penulis untuk mengatasi permasalahan yang dihadapi, yaitu perlu digunakan model dalam kegiatan pembelajaran yang mengakomodasi keaktifan siswa, bekerja kelompok, serta berpikir bersamasama dalam memecahkan suatu masalah di dalam kelas. Sehingga, diharapkan hasil belajar siswa dapat meningkat.

Salah satu model yang dapat memecahkan masalah tersebut adalah penerapan model pembelajaran Kooperatif tipe Think-Pair-Share (TPS). Model ini dikembangkan oleh Frank Lyman dan Arends ${ }^{1}$ menyatakan bahwa think-pair-share merupakan suatu cara yang efektif untuk membuat variasi suasana pola diskusi kelas dan memberi siswa lebih banyak waktu berfikir, merespon dan saling membantu siswa satu sama lain. Ini juga sesuai dengan hasil penelitian terdahulu antara lain, Putri Yuanita ${ }^{2}$ dan Marlina $^{3}$ menunjukkan bahwa pembelajaran matematika dengan menggunakan model pembelajaran kooperatif tipe TPS (Think-Pair-Share) dapat meningkatkan hasil belajar matematika serta menumbuhkan sikap positif pada siswa. Berdasarkan latar belakang tersebut maka penulis dilakukan penelitian dengan judul meningkatkan hasil belajar matematika melalui penerapan pembelajaran kooperatif tipe think-pair-share (TPS) pada siswa kelas VII B SMP Negeri 10 Ujung Loe Kabupaten Bulukumba.

1 Trianto, Model-Model Pembelajaran Inovatif Berorientasi Konstruktivis (Jakarta: Prestasi Pustaka Publisher, 2007).

2 Putri Yuanita and Titi Solfitri, "Analisis Kesalahan Siswa Menyelesaikan Soal Matematika Materi Pokok Bangun Datar Segiempat Pada Pelaksanaan Pembelajaran Kooperatif Pendekatan Struktural Think Pair Square (TPS)," Al-Khwarizmi : Jurnal Pendidikan Matematika dan IImu Pengetahuan Alam 2, no. 2 (October 5, 2014): 127-42, https://doi.org/10.24256/akh.v2i2.207.

3 Marlina, Hajidin, and M. Ikhsan, "Penggunaan Model Pembelajaran Kooperatif Tipe Think-Pair-Share (TPS) Untuk Meningkatkan Kemampuan Komunikasi Dan Disposisi Matematis Siswa Di SMA Negeri 1 Bireuen | . | Jurnal Didaktik Matematika," accessed January 8 , 2018, http://webcache.googleusercontent.com/search?q=cache:qG1rMHl39XkJ:www.jurnal.unsyi ah.ac.id/DM/article/view/1341+\&cd=10\&hl=id\&ct=clnk\&gl=id\&client=firefox-b-ab. 


\section{Kerangka Teoretis}

Matematika merupakan proses psikologi. Mempelajari matematika tidak hanya berhubungan dengan bilangan, operasi-operasinya melainkan berkenaan juga dengan ide-ide, struktur-struktur dan hubungannya diatur secara logis. Ciri utama matematika adalah penalaran deduktif, yaitu kebenaran suatu konsep atau pertanyaan diperoleh sebagai akibat logis dari kebenaran sebelumnya sehingga ada kaitan antara konsep pernyataan dalam matematika bersifat konsisten.

Hasil belajar adalah kemampuan yang dimiliki siswa setelah ia menerima pengalaman belajarnya. Hasil belajar mempunyai peranan penting dalam proses pembelajaran. Salah satu diantaranya adalah memberikan informasi kepada guru tentang kemajuan siswa dalam upaya mencapai tujuan - tujuan belajarnya melalui kegiatan belajar. Hasil belajar dibagi tiga macam, yaitu4:

a. Keterampilan dan kebiasaan.

b. Pengetahuan dan pengertian.

c. Sikap dan cita-cita yang masing-masing golongan dapat diisi dengan bahan yang ada pada kurikulum sekolah.

Pembelajaran kooperatif merupakan sebuah kelompok strategi pengajaran yang melibatkan siswa bekerja secara berkolaborasi untuk mencapai tujuan bersama. Menurut Eggen and Kauchak pembelajaran kooperatif disusun dalam sebuah usaha untuk meningkatkan partisipasi siswa, memfasilitasi siswa dengan pengalaman sikap kepemimpinan dan membuat keputusan dalam kelompok, serta memberikan kesempatan pada siswa untuk berinteraksi dan belajar besama-sama siswa yang berbeda latar belakangnya 5 .

Pembelajaran kooperatif terbagi atas 4 macam model yaitu STAD (Student Teams Achievement Division), Investigasi Kelompok (Teams Games

4 Nana Sudjana, Penilaian Hasil Proses Belajar Mengajar (Bandung: PT. Remaja Rosdakarya, 2008).

5 Trianto, Model-Model Pembelajaran Inovatif Berorientasi Konstruktivis. 


\section{Meningkatkan Hasil Belajar Matematika...}

Tournaments atau TGT), Jigsaw dan pendekatan struktural meliputi Think Pair Share (TPS) dan Numbered Head Together (NHT) ${ }^{6}$.

Adapun manfaat pembelajaran kooperatif bagi siswa dengan hasil belajar rendah menurut Linda Lundgren adalah sebagai berikut ${ }^{7}$ :

1) Meningkatkan pencurahan waktu pada tugas.

2) Rasa harga diri menjadi lebih tinggi.

3) Penerimaan terhadap perbedaan individu menjadi lebih besar.

4) Motivasi lebih besar.

5) Konflik antar pribadi berkurang.

6) Meningkatkan kebaikan budi, kepekaan, dan toleransi

Terdapat 6 langkah utama atau tahapan di dalam pelajaran yang menggunakan pembelajaran kooperatif seperti yang terlihat pada Tabel 1 berikut: 8

Tabel 1. Sintaks Pembelajaran Kooperatif

\begin{tabular}{|c|c|}
\hline Fase & Tingkah laku Guru \\
\hline \multicolumn{2}{|l|}{ Fase -1} \\
\hline $\begin{array}{l}\text { Menyampaikan tujuan dan } \\
\text { memotivasi siswa }\end{array}$ & $\begin{array}{l}\text { Guru menyampaikan semua tujuan } \\
\text { pembelajaran yang ingin dicapai } \\
\text { pada pelajaran tersebut dan } \\
\text { memotivasi siswa belajar }\end{array}$ \\
\hline \multicolumn{2}{|l|}{ Fase -2} \\
\hline Menyajikan Informasi & $\begin{array}{l}\text { Guru menyajikan informasi kepada } \\
\text { siswa dengan jalan demonstrasi atau } \\
\text { lewat bahan bacaan }\end{array}$ \\
\hline \multicolumn{2}{|l|}{ Fase -3} \\
\hline $\begin{array}{l}\text { Mengorganisasikan siswa kedalam } \\
\text { kelompok-kelompok belajar }\end{array}$ & $\begin{array}{l}\text { Guru menjelaskan kepada siswa } \\
\text { bagaimana caranya membentuk } \\
\text { kelompok belajar dan membantu } \\
\text { setiap kelompok agar melakukan } \\
\text { transisi secara efisien }\end{array}$ \\
\hline $\begin{array}{l}\text { Fase - } 4 \\
\text { Membimbing kelompok bekerja dan } \\
\text { belajar }\end{array}$ & $\begin{array}{l}\text { Guru membimbing kelompok- } \\
\text { kelompok belajar pada saat mereka } \\
\text { mengerjakan tugas mereka }\end{array}$ \\
\hline \multicolumn{2}{|l|}{${ }^{6}$ Trianto. } \\
\hline $\begin{array}{l}{ }^{7} \text { Muslimin Ibrahim, Pembelajaran } 1 \\
\text { 2005). }\end{array}$ & Kooperatif (Surabaya: Unesa University Press, \\
\hline
\end{tabular}




\begin{tabular}{ll}
\hline Fase -5 & $\begin{array}{l}\text { Guru mengevaluasi hasil belajar } \\
\text { Evaluasi }\end{array}$ \\
$\begin{array}{l}\text { tentang materi yang telah dipelajari } \\
\text { atau masing-masing kelompok } \\
\text { mempresentasikan hasil kerjanya. }\end{array}$ \\
\hline $\begin{array}{l}\text { Fase }-6 \\
\text { Memberikan penghargaan }\end{array}$ & $\begin{array}{l}\text { Guru mencari cara-cara untuk } \\
\text { menghargai baik upaya maupun hasil } \\
\text { belajar individu dan kelompok. }\end{array}$ \\
\hline
\end{tabular}

TPS singkatan dari Think-Pair-Share atau Berpikir-BerpasanganBerbagi, merupakan jenis pembelajaran kooperatif yang dirancang untuk mempengaruhi pola interaksi siswa ${ }^{9}$. TPS merupakan salah satu model pembelajaran yang dikembangkan dari teori kontrukivisme yang merupakan perpaduan antara belajar secara mandiri dan belajar secara kelompok. TPS memiliki prosedur yang ditetapkan secara eksplisit untuk memberi siswa waktu lebih banyak untuk berfikir, menjawab dan saling membantu satu sama lain. Misalkan seorang guru baru saja menyelesaikan suatu penyajian singkat, atau siswa telah membaca suatu tugas dan guru menginginkan siswa memikirkan lebih mendalam tentang apa yang telah dijelaskan atau dialami. Untuk itu guru dapat menerapkan langkah-langkah pembelajaran Think-Pair-Share sebagai berikut:10

Tahap I : Thinking (berpikir). Guru mengajukan pertanyaan atau soal yang berhubungan dengan pelajaran. Selanjutnya siswa diminta untuk memikirkan jawaban pertanyaan atau soal tersebut secara mandiri untuk beberapa saat.

Tahap II : Pairing (berpasangan). Guru meminta siswa berpasangan dengan siswa yang lain untuk mendiskusikan apa yang telah dipikirkan pada tahap pertama. Interaksi pada tahap ini diharapkan dapat berbagi jawaban atau berbagi ide. Biasanya guru memberi waktu 4-5 menit untuk berpasangan.

\footnotetext{
${ }^{9}$ Trianto, Model-Model Pembelajaran Inovatif Berorientasi Konstruktivis.

${ }^{10}$ Muslimin Ibrahim, Pembelajaran Kooperatif.
} 


\section{Meningkatkan Hasil Belajar Matematika...}

Tahap III : Sharing (berbagi). Pada tahap akhir ini, guru meminta kepada pasangan untuk berbagi dengan seluruh kelas tentang apa yang telah mereka bicarakan.

Adapun kelebihan pembelajaran Kooperatif tipe Think Pair Share (TPS) sebagai berikut:

1) Memungkinkan siswa untuk merumuskan dan mengajukan pertanyaanpertanyaan mengenai materi yang akan diajarkan karena secara tidak langsung memperoleh contoh pertanyaan yang diajukan oleh guru, serta memperoleh kesempatan untuk memikirkan materi yang diajarkan.

2) Siswa akan terlatih menerapkan konsep karena bertukar pendapat dan pemikiran dengan temannya untuk mendapatkan kesepakatan dalam memecahkan masalah.

3) Siswa lebih aktif dalam pembelajaran karena menyelesaikan tugasnya dalam kelompok.

4) Siswa memperoleh kesempatan untuk mempresentasikan hasil diskusinya dengan seluruh siswa sehingga ide ada yang menyebar.

\section{Metode dan Hasil Penelitian}

Penelitian ini adalah penelitian tindakan kelas (Classroom Action Research) yang terdiri atas dua siklus. Setiap siklus terdiri dari beberapa tahapan pelaksanaan yaitu : 1. Perencanaan, 2. Pelaksanaan Tindakan, 3. Pengamatan atau Observasi, 4. Refleksi. Penelitian ini dilakukan di SMP Negeri 3 Ujung Loe Kab. Bulukumba yang terletak di jalan poros BiraBulukumba dengan subyek penelitian ini adalah siswa kelas VIIB semester ganjil tahun pelajaran 2016/2017 sebanyak 30 orang yang terdiri dari 15 siswa laki-laki dan 15 siswa perempuan. Instrumen dan teknik pengumpulan penelitian ini adalah observasi, angket, tes hasil belajar. Teknik analisis data yang digunakan analisis kualitatif dan analisis kuantitatif. Analisis kualitatif yaitu analisis data tentang sikap, minat dan motivasi yang diperoleh dari lembar observasi dan tanggapan siswa. Sedangkan, analisis kuantitatif yaitu analisis data hasil belajar dengan menggunakan analisis statistik deskriptif serta kategorisasi data. 
Keberhasilan tindakan diukur dengan pencapaian ketuntasan belajar yang disesuaikan dengan Kriteria Ketuntasan Minimum (KKM) yang ditetapkan pada mata pelajaran matematika di SMP Negeri 10 Ujung Loe Kab. Bulukumba adalah 65. Hasil analisis kuantitatif dan hasil analisis kualitatif pada siklus I dan siklus II diketahui bahwa peningkatan hasil belajar matematika dan frekuensi keaktifan siswa kelas VII B SMP Negeri 10 Ujung Loe Kab. Bulukumba setelah diterapkan pembelajaran Kooperatif Tipe TPS (Think-Pair-Share) mengalami peningkatan. Hal ini dapat dilihat pada Tabel 2 berikut ini

Tabel 2. Perbandingan Hasil Belajar Matematika Siswa Kelas VII B SMP Negeri 10 Ujung Loe Kab. Bulukumba pada Siklus I dan Siklus II

\begin{tabular}{ccccccc}
\hline \multirow{2}{*}{ Siklus } & \multicolumn{3}{c}{ Skor Hasil Belajar Siswa } & \multicolumn{2}{c}{ Ketuntasan } \\
\cline { 2 - 7 } & Maks & Min & Mean & Std Dev & Tuntas & $\begin{array}{c}\text { Tdk } \\
\text { Tuntas }\end{array}$ \\
\hline I & 80 & 5 & 39,50 & 24,58 & 7 & 23 \\
\hline II & 100 & 10 & 69,50 & 24,99 & 21 & 9 \\
\hline
\end{tabular}

Sumber: Data olahan

Berdasarkan Tabel 2 tersebut menunjukkan bahwa pada siklus I ratarata hasil belajar siswa sebesar 39,50, standar deviasi 24,58 atau berada pada kategori rendah meningkat menjadi 69,50, standar deviasi 24,99 atau berada kategori tinggi pada siklus II. Sedangkan, banyaknya siswa yang tuntas secara perorangan pada siklus I sebanyak 7 siswa meningkat menjadi 21 siswa pada siklus II. Sebaliknya, terjadi penurunan jumlah siswa yang tidak tuntas belajar dari 23 siswa pada siklus I menjadi 9 siswa pada siklus II.

Disamping terjadi peningkatan hasil belajar selama penelitian pada siklus I dan siklus II tercatat sejumlah perubahan yang terjadi pada sikap siswa terhadap pelajaran matematika. Perubahan tersebut diperoleh dari observasi pada tiap pertemuan pada siklus I dan siklus II. Adapun perubahan-perubahan yang terjadi sebagai berikut: Meningkatnya persentase kehadiran siswa (absensi siswa) pada saat pembelajaran matematika. Pada siklus I kehadiran siswa sebesar 98,88\% dan pada 


\section{Meningkatkan Hasil Belajar Matematika...}

siklus II menjadi 100\%; Keaktifan siswa dalam mengikuti proses pembelajaran mengalami peningkatan dari siklus I ke siklus II. Frekuensi dan persentase keaktifan ini ditandai dengan beberapa hal yaitu : Terjadi peningkatan siswa yang mengajukan pertanyaan pada siklus I sebanyak 11 siswa dengan persentase $12,22 \%$ dan pada siklus II sebanyak 16 siswa dengan persentase 17,78\%. Hal ini disebabkan karena siswa mulai termotivasi untuk belajar dan tidak canggung untuk bertanya kepada guru mengenai materi yang belum dimengerti; Persentase siswa yang menjawab pertanyaan atau permasalah yang diajukan guru semakin meningkat dari siklus I sebesar 8,89\% sebanyak 8 siswa dan pada siklus II sebesar 14,44\% sebanyak 13 siswa; Siswa yang aktif berdiskusi pasangan, yang ditunjukkan dengan peningkatan persentase dari siklus I sebesar 62,22\% sebanyak 56 siswa dan siklus II sebesar 73,33\% sebanyak 66 siswa; Siswa yang semakin aktif mempresentasekan hasil diskusi dari siklus I sebesar 11,11\% dan pada siklus II meningkat menjadi 15,56\%; Persentase siswa siswa yang melakukan kegiatan lain semakin menurun dari siklus I sebesar 7,78\% sebanyak 6 siswa dan pada siklus II sebesar 2,22\% sebanyak 2 siswa; Banyaknya siswa yang mengumpul PR pada siklus I sebesar $97,77 \%$ dan meningkat pada siklus II sebesar $100 \%$

Dari hasil analisis kuantitatif dan kualitatif terlihat bahwa pada dasarnya pelaksanaan pembelajaran dengan menggunakan model pembelajaran kooperatif tipe Think-Pair-Share (TPS) dapat memberikan motivasi belajar siswa selain terjadi peningkatan rata-rata hasil belajar dari siklus I ke siklus II. Juga terjadi perubahan sikap siswa dalam proses pembelajaran dari siklus I ke siklus II.

Hal ini menunjukkan bahwa siswa memiliki kemauan, minat dan motivasi dalam mengikuti proses pembelajaran. Dengan demikian dapat disimpulkan bahwa dengan pembelajaran kooperatif tipe Think-Pair-Share (TPS) dapat meningkatkan hasil belajar siswa SMP Negeri 10 Ujung Loe Kabupaten Bulukumba. 


\section{Penutup}

Berdasarkan hasil penelitian dan pembahasan dapat disimpulkan: (1). Hasil belajar matematika siswa kelas VIIB semester 1 SMP Negeri 3 Ujung Loe Kab. Bulukumba dapat ditingkatkan dengan model pembelajaran kooperatif tipe TPS (Think-Pair-Share), ditunjukkan skor rata-rata hasil belajar siswa pada siklus I dari 39,50 berada dalam kategori rendah menjadi 69,50 berada dalam kategori tinggi pada siklus II. Siswa yang tuntas pada siklus I sebanyak 7 orang meningkat menjadi 21 orang pada siklus II. Sebaliknya siswa yang tidak tuntas mengalami penurunan pada siklus I sebanyak 23 orang dan pada siklus II sebanyak 9 orang.. (2). Penerapan model pembelajaran Kooperatif Tipe TPS (Think-Pair-Share) dalam proses pembelajaran dapat meningkatkan keaktifan siswa kelas VII B SMP Negeri 3 Ujung Loe Kab. Bulukumba., (3). Adanya respon positif siswa dengan diterapkannya pembelajaran kooperatif tipe Think-PairShare (TPS). Siswa menganggap dengan diterapkannya pembelajaran kooperatif tipe Think-Pair-Share (TPS), siswa dapat saling tukar-menukar pendapat antara kelompok yang satu dengan kelompok yang lain, melatih siswa untuk berani tampil di depan kelas untuk menjelaskan pendapatnya dan membantu siswa yang kurang pandai dalam menyelesaikan soal 


\section{Daftar Pustaka}

Marlina, Hajidin, and M. Ikhsan. "Penggunaan Model Pembelajaran Kooperatif Tipe Think-Pair-Share (TPS) Untuk Meningkatkan Kemampuan Komunikasi Dan Disposisi Matematis Siswa Di SMA Negeri 1 Bireuen | . | Jurnal Didaktik Matematika." Accessed January 8, 2018. http://webcache.googleusercontent.com/search?q=cache:qG1rMHl39X kJ:www.jurnal.unsyiah.ac.id/DM/article/view/1341+\&cd=10\&hl=id\& $\mathrm{ct}=\mathrm{clnk} \& \mathrm{gl}=\mathrm{id} \& \mathrm{client}=$ firefox-b-ab.

Muslimin Ibrahim. Pembelajaran Kooperatif. Surabaya: Unesa University Press, 2005.

Sudjana, Nana. Penilaian Hasil Proses Belajar Mengajar. Bandung: PT. Remaja Rosdakarya, 2008.

Trianto. Model-Model Pembelajaran Inovatif Berorientasi Konstruktivis. Jakarta: Prestasi Pustaka Publisher, 2007.

Yuanita, Putri, and Titi Solfitri. “Analisis Kesalahan Siswa Menyelesaikan Soal Matematika Materi Pokok Bangun Datar Segiempat Pada Pelaksanaan Pembelajaran Kooperatif Pendekatan Struktural Think Pair Square (TPS)." Al-Khwarizmi: Jurnal Pendidikan Matematika dan Ilmu Pengetahuan Alam 2, no. 2 (October 5, 2014): 127-42. https://doi.org/10.24256/akh.v2i2.207. 
Muhammad Awal Nur

Halaman ini sengaja dikosongkan

Al-Khwarizmi - 154 